Editorial

\title{
Special Issue Sustainable Interdisciplinarity: Human-Nature Relations
}

\author{
Giuseppe T. Cirella ${ }^{1, *(D)}$ and Alessio Russo ${ }^{2}$ D \\ 1 Faculty of Economics, University of Gdansk, 81-824 Sopot, Poland \\ 2 School of Arts, University of Gloucestershire, Francis Close Hall Campus, Cheltenham GL50 4AZ, UK; \\ arusso@glos.ac.uk \\ * Correspondence: gt.cirella@ug.edu.pl
}

Received: 15 December 2019; Accepted: 17 December 2019; Published: 18 December 2019

\begin{abstract}
Sustainable interdisciplinarity focuses on human-nature relations and a multitude of contemporary overlapping research between society and the environment. A variety of disciplines have played a large part in better understanding sustainable development since its high-profile emergence approximately a quarter century ago. At present, the forefront of sustainability research is an array of methods, techniques, and growing knowledge-base that considers past, present, and future pathways. Specific multi-disciplinary concentrations within the scope of societal changes, urban landscape transformations, international environmental comparative studies as well as key theories and dynamics relating to sustainable performance are explored. Specializations in complex sustainability issues address international governance arrangements, rules, and organizations-both public and private-within the scope of four themes: sustainability, human geography, environment, and interdisciplinary societal studies. This book contains eleven thoroughly refereed contributions concerning pressing issues that interlink sustainable interdisciplinarity with the presented themes in respect of the human-nature interface.
\end{abstract}

Keywords: sustainability; human geography; environment; interdisciplinary societal studies

\section{Introduction}

This Special Issue is comprised of eleven thoroughly refereed contributions that shed light on a wide array of research activities within four themes: sustainability, human geography, environment, and interdisciplinary societal studies. The themes exemplify sustainable interdisciplinarity and the human-nature relational interface. Over the past few decades, a number of societal-challenging changes have arisen, in particular the environmental movement, variations in dialogue regarding sustainable development, social adherence with technological innovation, and socio-political shifts of tolerable norms. These issues have sparked much attention, research, and scientific output [1,2]. Socially scientific-based applications regarding the questions of what human beings require and how compatible or, better yet, functional these requirements are with regard to the environment and co-habitancy with fellow species is the level of interdisciplinarity modern society weighs in on when dealing with this interface [3-7]. Elkington's [8,9] triple bottom line (TBL) concept, where environmental, social, and economic standpoints form the three pillars of sustainability, needs to consider the array of scientific complexities and questions that query combinative efforts of interlinking quantitative and qualitative data. Successfully connecting the two will better interlink sustainability-oriented practice and harmonize societies via TBL reporting [10]. In sustainability terms, developing and comparing a state-of-the-art rationale of societal changes from and between different areas merges a variety of key disciplines including geography, urban development, environmental management, sociology, ethics, and philosophy. 
In reference to the development of sustainable societies, there is a critical scope in terms of human interconnectedness with the world-around-us and the noise society bares. Noise, in this sense, is the busyness that societies, especially contemporary, levy on an individual [3]. If one were to assess this levy, it could be labelled, respectively, as weight $[11,12]$. In a sense, it would be an individual's level of effectiveness or aptitude to participation within society versus one's unproductiveness or imaginative state of thinking "outside of the box". Societies, especially contemporary ones, face diverse challenges that need to acknowledge functional, versus dysfunctional, action. This acknowledgement, evident from reviewing the chronology of art and usage of modern-day social media, relates to a growing worldwide concern of ideas and concepts that people from all scopes of life are probing. This concern correlates the human necessity of need and want at the individual level, and its coexistence and framing via day-to-day living. The level of harmonization societies exert is somewhat of a balancing act in which large scoped challenges such as rising inequality, loss of biodiversity, and armed conflict are at the core of bandage-like fixes that have been relatively inept. The need to rearrange human-nature relations is fundamental to trying to comprehend the noise in which functionality, between human beings and nature, defines societal sustainability. A sustainable society should relate not only to lifestyle, but to an aggregate thought pattern of decisions; touching upon the concept of what human beings need (i.e., for survival) versus want, and whether it is from a top down or bottom up (or another type of) viewpoint. Over the last few decades, similar forms of fragmentation have indicated exactly this via a cause and effect approach (e.g., increased individual indulgence and mass materialism versus the family institution and renovative or repair-like knowhow). This (dis)order, or some might say fragmentation, is a crossroad or transitional point in which forthcoming generations will live and work at a standard consequential to present-day actions.

\section{Synopsis of the Contributions}

The primary thesis of this Special Issue is to provide a set of innovative contributions regarding linkages between human beings and nature. Sustainable interdisciplinarity is broken down in terms of up-to-date interrelating research between society and our natural surroundings. Of the eleven contributions, nine focus on country-specific studies (i.e., China (two), Cambodia, Poland, Singapore, South Korea (three), and the Czech Republic), while one is written as an essay and another is a concept paper. The collection of contributions provide methodologies and innovative approaches that are useful for both scholars and professionals alike. The contributions were thoroughly refereed and accepted via single-blind review in adherence with MDPI's review guidelines. A synopsis of the Special Issue consists of the following contributions: Xie et al. [13] conceptualized the use of Ostrom's [14] social-ecological systems framework in the context of nature reserves in China by presenting a novel approach (i.e., the hybrid psycho-economic model) and interlinking collective forest management via a dynamic analysis of three case studies. Kim et al. [15] examined the notion of sustainable transformative economy based on community-based ecotourism in a remote area of eastern Cambodia. This contribution examined ecotourism development from the perspective of participation and economic impact. Most households acknowledged ecotourism had a positive impact on community TBL output, however, depleted natural resources and impact on local culture were some problems. As a low-impact alternative to standard commercial tourism, community-based ecotourism can become a transformative form of economics for local communities.

Bieliński et al. [16] investigated bike-sharing systems in Poland as a widely recognized eco-friendly mode of transportation that is able to assist in alleviating air pollution and traffic congestion. The identification of factors that correlated with the performance of bike-sharing systems were positively linked with urban population, tourism, number of bike stations per capita, congestion, bicycle pathway length, and higher temperature while precipitation was negatively linked. In another urban related study, Hu et al. [17] examined stakeholder collaboration on policymaking for sustainable water management in Singapore's hotel sector. This research applied policymaking, in terms of tourism value, through a dynamic network, where stakeholders come to a consensus on sustainability to 
investigate stakeholder collaboration within the city's policy domain. Prominent political and industry players were seen to have favorable network positions.

Next, three South Korean studies looked at urban planning and cityscape issues within the context of climatic variability and community development. First, Lee and Oh [18] developed an urban thermal environment management and planning system using mathematical climate simulation modeling to examine urban heat island and thermal environmental effects throughout Seoul. They analyzed meteorological models and applied geographic information system analysis methods to assess urban spatial change scenarios for future urban development. Second, Lee et al. [19] classified urban climate zones (also within Seoul) via spatial statistical analyses to help urban planners delineate clearer boundaries relative to a set of (pre-determined) spatial variables. The scope of the research — effectively—can be extended and applied to other cities to establish urban heat island counter measures within similar weather-related conditions. Third, An and Lee [20] considered nature in a city in the restorative project areas of Cheonggye Stream and Suseongdong Valley. The study explored the historical and cultural background of sustainable planning in the context between "city with nature" and "nature with culture".

Rybova [21] examined the sociodemographic characteristics of waste management and explored the notion of recyclability in the Czech Republic. This research focused on individual characteristics connected to ongoing demographic change as well as municipal level inputs before considering the spatial effects and regional specificity of that nation's recycling program. Zhang and Sun [22] undertook research that looked at attitudes toward genetically modified (GM) food safety among Chinese Internet users. The results indicated that $35.1 \%$ of respondents found GM food to be risky while $20.4 \%$ did not. Moreover, a higher percentage of younger respondents specified GM food as safe versus persons with higher levels of income and education who stated that it was risky. This contribution explores new insights into understanding the ideological influences on science development and sustainability.

Andreucci et al. [23] wrote an essay on designing urban green blue infrastructure for mental health and elderly wellbeing and presented a number of ways that exposure to and affiliation with nature have shown to support mental health as well as piece together key performance indicators (i.e., metrics) to monitor and adapt open spaces within the context of urban environments. Solutions are discussed and subsequent comparative critical analysis elucidated upon. Finally, Celadyn [24] framed a concept paper on interior architectural design for adaptive reuse by utilizing environmental sustainability principles. The design concept was based on the reintroduction of reclaimed or salvaged building material acquired from demolished or refurbished construction sites for interior structural reuse. Circular design methods and techniques were drawn up and the implementation of a resource efficiency strategy was used. The fulfilment of resource efficiency in conjunction with waste management effectiveness was also explored.

\section{Conclusions}

In conclusion, these contributions clearly exhibit an important focus on sustainable interdisciplinarity with specific human-nature relational overlaps between society and the environment. This Special Issue addresses a broad range of topics at the forefront of sustainability research. From a human geographical perspective, there is a growing knowledge base exemplar to many of the concerns sustainable societies must consider; this book interlinks this interdisciplinarity to the human-nature interface and overarching theme of sustainable development. Key work within related fields utilize integrated assessment, decision-aiding techniques, and emerging models that, for the most part, stray toward a rethinking. The notion of economizing society is by in large not accomplished by using current economic hypotheses (i.e., the economization of something will need to avoid waste and reduce outflow) [25,26]. Rees [27] argues that modernity and human beings are unsustainable, stating that unsustainability is an inevitable emerging property of the systemic interaction between contemporary technological society and the ecosphere. It is clear that contemporary societies struggle in this regard and continue to maintain the premise of anti-sustainable action where mass-affluence does not formulate 
advantageous human-nature relations but more often than not, the opposite. On the other hand, technology, like the extended hand of human ingenuity, should be distributed so that a greater number of people can acquire fuller, unrestricted access. The current parameters in which the international community integrates scientific information into decision-making is key to determining how innovation is justly circulated and efficiently developed. This relationship corresponds with significant concepts in "greener" societies and formulates designs that are based on governance innovativeness and equitable resource opportunities for all [28]. Earth encompasses fundamental rules for survival; this inscribes the premise for basic necessities as central and, if compliant, the harmonization and equilibrial change of society itself.

Author Contributions: Conceptualization, Investigation, Resources, and Writing—original draft preparation: G.T.C.; Validation and Writing-review and editing: G.T.C. and A.R.

Funding: This research received no external funding.

Acknowledgments: The editors express their gratefulness and gratitude to the reviewers for their support and critical and constructive comments. This has significantly improved the quality of the collection as well as academic output. The editors graciously extend their thanks to the editorial assistance office of MDPI for their support throughout the review and publication process of this Special Issue. This work was partly financed by the Polo Centre of Sustainability, Italy and the University of Gdansk, Poland in collaboration with the $2^{\text {nd }}$ International Conference on Sustainability, Human Geography, and Environment 2018 held in Cracow, Poland between 28 November-2 December 2018.

Conflicts of Interest: The authors declare no conflicts of interest.

\section{References}

1. Cirella, G.T.; Zerbe, S. Index of sustainable functionality: Procedural developments and application in Urat Front Banner, Inner Mongolia Autonomous Region. Int. J. Environ. Sustain. 2014, 10, 15-31. [CrossRef]

2. Cirella, G.T.; Tao, L.; Mohamed, S. An application of an adaptive quantitative method to measure the sustainability of the Gold Coast, Australia. J. Coast. Res. 2007, 50, 52-56.

3. Cirella, G.T.; Tao, L. Measuring sustainability: An application using the index of sustainable functionality in South East Queensland, Australia. Int. J. Interdiscip. Soc. Sci. 2008, 3, 231-240. [CrossRef]

4. Cirella, G.T.; Tao, L. An adaptive quantitative method to measure sustainability: An application for the State of Queensland, Australia. Int. J. Environ. Cult. Econ. Soc. Sustain. 2009, 5, 127-139. [CrossRef]

5. Russo, A.; Escobedo, F.J.; Cirella, G.T.; Zerbe, S. Edible green infrastructure: An approach and review of provisioning ecosystem services and disservices in urban environments. Agric. Ecosyst. Environ. 2017, 242, 53-66. [CrossRef]

6. Russo, A.; Cirella, G.T. Modern Compact Cities: How Much Greenery Do We Need? Int. J. Environ. Res. Public Health 2018, 15, 2180. [CrossRef]

7. Russo, A.; Cirella, G.T. Edible Green Infrastructure 4.0 for Food Security and Well-being: Campania Region, Italy. In International Guidelines on Urban and Territorial Planning. Compendium of Inspiring Practices: Health Edition; Quinlan, V., Ed.; UN Habitat, HS/080/18E: Nairobi, Kenya, 2018; p. 72.

8. Elkington, J. 25 Years Ago I Coined the Phrase “Triple Bottom Line." Here's Why It's Time to Rethink It. 2018. Available online: https://hbr.org/2018/06/25-years-ago-i-coined-the-phrase-triple-bottom-line-hereswhy-im-giving-up-on-it (accessed on 20 October 2019).

9. Elkington, J. Towards the Sustainable Corporation: Win-Win-Win Business Strategies for Sustainable Development. Calif. Manage. Rev. 1994, 36, 90-100. [CrossRef]

10. James, P. Urban Sustainability in Theory and Practice: Circles of Sustainability; Routledge: London, UK, 2015; ISBN 1138025720.

11. Imberger, J.; Mamouni, E.D.; Anderson, J.; Ng, M.; Nicol, S.; Veale, A. The index of sustainable functionality: A new adaptive, multicriteria measurement of sustainability-application to Western Australia. Int. J. Environ. Sustain. Dev. 2007, 6, 323-355. [CrossRef]

12. Cirella, G.T.; Zerbe, S. Quizzical societies: A closer look at sustainability and principles of unlocking its measurability. Int. J. Sci. Soc. 2014, 5, 29-45. [CrossRef] 
13. Xie, Y.; Wen, Y.; Cirella, G.T. Application of Ostrom's Social-Ecological Systems Framework in Nature Reserves: Hybrid Psycho-Economic Model of Collective Forest Management. Sustainability 2019, 11, 6929. [CrossRef]

14. Ostrom, E. Governing the Commons: The evolution of Institutions for Collective Action; Cambridge University Press: Cambridge, UK, 1990; ISBN 0521405998.

15. Kim, M.; Xie, Y.; Cirella, G.T. Sustainable Transformative Economy: Community-Based Ecotourism. Sustainability 2019, 11, 4977. [CrossRef]

16. Bieliński, T.; Kwapisz, A.; Ważna, A. Bike-Sharing Systems in Poland. Sustainability 2019, 11, 2458. [CrossRef]

17. Hu, X.; Lovelock, B.; Ying, T.; Mager, S. Stakeholder Collaboration on Policymaking for Sustainable Water Management in Singapore's Hotel Sector: A Network Analysis. Sustainability 2019, 11, 2360. [CrossRef]

18. Lee, D.; Oh, K. Developing the Urban Thermal Environment Management and Planning (UTEMP) System to Support Urban Planning and Design. Sustainability 2019, 11, 2224. [CrossRef]

19. Lee, D.; Oh, K.; Jung, S. Classifying Urban Climate Zones (UCZs) Based on Spatial Statistical Analyses. Sustainability 2019, 11, 1915. [CrossRef]

20. An, D.; Lee, J.-Y. Influence and Sustainability of the Concept of Landscape Seen in Cheonggye Stream and Suseongdong Valley Restoration Projects. Sustainability 2019, 11, 1126. [CrossRef]

21. Rybova, K. Do Sociodemographic Characteristics in Waste Management Matter? Case Study of Recyclable Generation in the Czech Republic. Sustainability 2019, 11, 2030. [CrossRef]

22. Zhang, Y.; Sun, Y. The Effect of Ideology on Attitudes toward GM Food Safety among Chinese Internet Users. Sustainability 2018, 10, 4326. [CrossRef]

23. Andreucci, M.B.; Russo, A.; Olszewska-Guizzo, A. Designing Urban Green Blue Infrastructure for Mental Health and Elderly Wellbeing. Sustainability 2019, 11, 6425. [CrossRef]

24. Celadyn, M. Interior Architectural Design for Adaptive Reuse in Application of Environmental Sustainability Principles. Sustainability 2019, 11, 3820. [CrossRef]

25. Russo, A.; Cirella, G.T. Biophilic Cities: Planning for Sustainable and Smart Urban Environments. In Smart Cities Movement in BRICS; Aijaz, R., Ed.; Observer Research Foundation and Global Policy Journal: London, UK, 2017; pp. 153-159. ISBN 978-81-86818-29-9.

26. Cirella, G.; Iyalomhe, F.; Jensen, A.; Akiyode, O. Exploring Community of Practice in Uganda's Public Sector: Environmental Impact Assessment Case Study. Sustainability 2018, 10, 2502. [CrossRef]

27. Rees, W. What's blocking sustainability? Human nature, cognition, and denial. Sustain. Sci. Pract. Policy 2010, 6, 13-25. [CrossRef]

28. Cirella, G.T.; Zerbe, S. Sustainable Water Management and Wetland Restoration in Settlements of Continental-Arid Central ASIA; Bozen Univesity Press: Bozen, Italy, 2014; ISBN 978-88-6046-069-1. 